\title{
Evaluating Approaches to Teaching and Learning Chinese Vocabulary From the Learning Theories Perspective: An Experimental Case Study
}

\author{
Katja SIMONČIČ \\ University of Ljubljana, Slovenia \\ katja.skitek@siol.net
}

\begin{abstract}
With Chinese language gaining more and more popularity among Slovenian students and with the growing number of learners of Chinese as a foreign language in Slovenia and elsewhere, it is crucial to find an approach that will lead to high quality and long-term knowledge of Chinese and that will motivate learners to continue learning.

We can speak of two basic approaches to teaching Chinese vocabulary: the approach that first introduces pronunciation and the approach that simultaneously introduces pronunciation and character. The key question that arises is which of the two approaches leads to high quality and long-term knowledge? To answer the question an experimental case study was carried out at Ljubljana's Faculty of Arts in the academic year 2011/2012. The case study showed that the approach that simultaneously introduces pronunciation and character and is based on the key principles of constructivist learning theory had beneficial effects on the students in terms of motivation and quality of knowledge of Chinese vocabulary.
\end{abstract}

Key words: Chinese vocabulary; didactics; learning theories; Confucianism; experimental case study

\section{Povzetek}

Ker kitajščina kot tuji jezik postaja vedno bolj priljubljena med učenci v Sloveniji in po celem svetu, je nujno najti pristop, ki bo vodil $v$ kakovostno in dolgotrajno znanje in ki bo motiviral učence $k$ nadaljnjemu učenju kitajščine.

Lahko govorimo o dveh pristopih $k$ poučevanju kitajskega besedišča: pristop, ki najprej uvaja izgovorjavo, in pristop, ki hkrati uvaja izgovorjavo in pismenko. Ključno vprašanje, ki se pri tem poraja, je, kateri od obeh pristopov vodi $v$ bolj kakovostno in dolgotrajno znanje? $\mathrm{V}$ iskanju odgovora na to vprašanje je bila na Filozofski fakulteti v Ljubljani v študijskem letu 2011/2012 izvedena eksperimentalna študija primera, ki je pokazala, da je pristop, ki hkrati uvaja izgovorjavo in pismenko in je osnovan na konstruktivistični teoriji učenja, pripomogel k večji motivaciji med učenci ter bolj kakovostnemu znanju kitajskih pismenk.

Ključne besede: kitajsko besedišče; didaktika; teorije učenja; konfucianizem; eksperimentalna študija primera 


\section{Introduction}

There have been and still are many debates about how to teach Chinese as a foreign language (in continuation CFL), but according to Everson (2009) the lack of a common consent and general guidelines has led to very diverse approaches to teaching CFL. Among the researchers of how to teach CFL the debates evolve mostly around 5 themes as Xing (2006) points out:

1. elaboration of a more relevant curriculum,

2. grammar,

3. listening comprehension and oral communication,

4. reading comprehension and written communication,

5. use of technology in the CFL class and influence of culture.

Even though researchers like Lü (2006), Xiao (2006) and Xing (2006) have started to focus on vocabulary there is still a lack of consent and researches on how or whether to teach Chinese vocabulary as a whole at the beginning of the teaching process or whether to teach tones, character, pinyin and meaning as separate components.

\section{Chinese vocabulary}

When researching and finding guidelines on how to teach Chinese vocabulary, it is necessary to outline what exactly does it mean to know and comprehend a Chinese word?

Ur (1996) and Jesenovec (2004) say that knowing a word means knowing its grammatical category, usage, meaning and form. If we look at a Chinese word we can see that knowing a Chinese word means knowing its grammatical features (including usage), meaning, pronunciation and written form (character).

Since Slovenian language is not a tonal language and uses Roman alphabet it is obvious that for Slovenian students there are 2 aspects of Chinese words that need special attention especially when teaching CFL to beginners: pronunciation (especially tones) and character. In addition, the most commonly taught languages in Slovenian schools are German, English, French and Spanish. Chinese language is therefore with its characteristics something completely new and unknown for Slovenian students.

But still there is one more component of Chinese words that need to be addressed, the system for writing Chinese words with the Roman alphabet called pinyin. How can Slovenian students link a character with its pronunciation? It is practically impossible without pinyin. When addressing the issue of how to teach Chinese vocabulary, there are not only three, but four (if we leave the grammatical aspects out) aspects that need special attention: pronunciation (especially tones), character, pinyin and meaning. 


\subsection{Approaches to teaching Chinese vocabulary}

The key difference in approaches to teaching Chinese vocabulary is in separating or joining the word's components: pronunciation, character and meaning. Xing (2006) outlines two basic approaches to teaching Chinese vocabulary:

1. the approach that first introduces pronunciation and

2. the approach that simultaneously introduces pronunciation and character.

The advantage of the first approach is according to Xing (ibid.) that students can master Chinese pronunciation before starting to learn characters. Chinese researchers like Cui (2010) say that 12 days should be a minimum for teaching pronunciation. On the other hand there are disadvantages of this approach that need to be highlighted.

Firstly, focusing on pronunciation and consequently on pinyin distracts the student from the word's true graphic form (character). When students start to learn characters they are relying too much on pinyin instead of concentrating on characters and their structure (Xing 2006).

Secondly, focusing on pronunciation means that the students are not learning Chinese words as a whole and have difficulties when learning Chinese vocabulary such as not connecting the structure of Chinese characters with the pronunciation and meaning, relying too much on pinyin and not perceiving Chinese words as a whole (ibid.).

Thirdly, teaching and learning only pronunciation at the beginning also raises the question of motivation. Concentrating on pronunciation in the first weeks or months means that the students will have very little knowledge of the Chinese language in general, but will only master Chinese pronunciation. After learning CFL for a month the student will therefore not be able to greet or make small basic conversation in Chinese, let alone write basic communication structures in characters. If after a month a student will have very little knowledge of Chinese and will only master the Chinese pronunciation, how motivated will he be to continue learning CFL?

Even though there obviously is a general consent that pronunciation is so important it cannot be left out of the teaching process since both approaches include teaching pronunciation at the beginning, we cannot say the same for teaching characters. Wang (1998) presents three approaches to teaching characters:

1. teaching characters according to radicals,

2. teaching characters according to their frequency in usage and

3. not teaching characters.

According to Wang (ibid.) the last one was prevailing in USA, because Chinese is a tough enough language even without learning characters. This seems to be also the opinion of one of USA's most important sinologists DeFrancis (1976a and 1976b) whose textbooks [Beginning Chinese] (DeFrancis 1976a and 1976b) for teaching and 
learning CFL were one of the more popular textbooks for teaching CFL and were used in Slovenia likewise. Even in the $20^{\text {th }}$ century there are still textbooks published in the USA that don't include characters at all, for example [Chinese for Dummies] (Abraham 2005) and [Complete Mandarin Chinese] (Lai 2006). But characters are a fundamental part of Chinese language and hold many information regarding their history, meaning and pronunciation. If the student is aware of the character's structure he can learn how to read this information. Even more, characters are an important part of the Chinese culture, so is it really permissible not to teach them?

Research carried out and published by Ye (2011) deals with the question of when to include characters in the teaching process of beginners. The research was carried out in USA and showed that students enjoyed learning Chinese characters very much. From the student's point of view not teaching characters is inadmissible, since characters are such an interesting aspect of the Chinese language. But as Ye (ibid.) underlines it is very important for a teacher not to overload the students with the quantity of characters as they are still difficult for a student to learn especially at the beginning. When discussing whether to teach characters at the beginning or not, maybe the real question is not whether to teach them but how to teach them in order to help students understand their structure and facilitate the learning process.

It is essential to look at the background of the basic approaches to teaching Chinese vocabulary. As Everson (2009) points out the teachers of CFL have been forced to create different approaches and methods to teaching CFL according to their own experience due to the lack of a general consent and guidelines. But what is the theoretical background of these approaches? How have different learning theories on one hand and Confucian tradition on the other hand left an impact on them?

\section{Learning theories and Confucian view on learning and teaching}

Throughout the history there have been and still are different theories on what is the essence of learning, how we learn, what is the role of the teacher and the student in the learning process, the role of mistakes in the learning process etc. To evaluate approaches to teaching and learning CFL I have focused my attention on three learning theories: behaviorism, cognitivism and constructivism.

Authors like Batistič Zorec (2003), Driscoll (2000), Lightbown and Spada (2006) and Skela (2008) place behaviorism and cognitivism on different, sometimes opposing poles due to the very different, sometimes opposing views the two learning theories have on the role of the teacher, student, mistake and environment on learning. If behaviorism and cognitivism are on opposite sides, where should we place constructivism? As Fletcher (2008) explains constructivism is, like cognitivism, many times perceived as opposite to behaviorism, but in his opinion the two learning theories should be perceived as complementary. Constructivist learning theory is not a learning theory that excludes the key principles of other learning theories, but rather combines different principles basing on the key principle of constructing 
knowledge in the search of finding high quality approaches and methods to teaching and learning (Marentič Požarnik 2008, Plut Pregelj 2008). Let us take a closer look at the key principles of the three learning theories as shown in Table 1.

Table 1: Key principles of behaviorism, cognitivism, and constructivism

\begin{tabular}{|c|c|c|c|}
\hline & BEHAVIORISM & COGNITIVISM & CONSTRUCTIVISM \\
\hline $\begin{array}{l}\text { NATURE VS. } \\
\text { NURTURE }\end{array}$ & $\begin{array}{l}\text { Environment in which } \\
\text { the child is raised } \\
\text { determines his personal } \\
\text { characteristics. }\end{array}$ & $\begin{array}{l}\text { Cognitivists don't deny } \\
\text { the role of } \\
\text { environment, but focus } \\
\text { their attention on } \\
\text { mental states and } \\
\text { mental development in } \\
\text { terms of maturational } \\
\text { changes. }\end{array}$ & $\begin{array}{l}\text { Nature and nurture are } \\
\text { equally important as } \\
\text { they are } \\
\text { complementary. }\end{array}$ \\
\hline LEARNING & $\begin{array}{l}\text { The key in the learning } \\
\text { process is changing the } \\
\text { environment for the } \\
\text { learning to begin and } \\
\text { progress. }\end{array}$ & $\begin{array}{l}\text { Previous knowledge and } \\
\text { understanding of } \\
\text { learning content and } \\
\text { concepts are crucial. }\end{array}$ & $\begin{array}{l}\text { Learning is an active, } \\
\text { constructive, } \\
\text { cumulative and goal- } \\
\text { oriented process. }\end{array}$ \\
\hline $\begin{array}{l}\text { THE ROLE OF } \\
\text { THE STUDENT }\end{array}$ & $\begin{array}{l}\text { The student is passive in } \\
\text { terms that he cannot } \\
\text { participate in the } \\
\text { decisions regarding the } \\
\text { learning process. The } \\
\text { student's role is to } \\
\text { follow and trust the } \\
\text { teacher completely. }\end{array}$ & $\begin{array}{l}\text { The student has an } \\
\text { active role in the } \\
\text { learning process as he } \\
\text { relates all the new } \\
\text { information with his } \\
\text { previous knowledge. }\end{array}$ & $\begin{array}{l}\text { The student } \\
\text { independently } \\
\text { constructs his own } \\
\text { knowledge and } \\
\text { develops different skills } \\
\text { with his own activity. } \\
\text { The student is very } \\
\text { active in the learning } \\
\text { process as he is part of } \\
\text { the decision making } \\
\text { process and regulates } \\
\text { his own learning. }\end{array}$ \\
\hline $\begin{array}{l}\text { THE ROLE OF } \\
\text { THE TEACHER }\end{array}$ & $\begin{array}{l}\text { The teacher is the most } \\
\text { important part of the } \\
\text { learning process as he is } \\
\text { the one that controls, } \\
\text { leads and regulates the } \\
\text { learning process. }\end{array}$ & $\begin{array}{l}\text { The teacher adapts to } \\
\text { student's needs and } \\
\text { understands that } \\
\text { students enter the } \\
\text { learning process with } \\
\text { different levels of } \\
\text { previous knowledge. His } \\
\text { role is to create } \\
\text { opportunities for } \\
\text { learning. }\end{array}$ & $\begin{array}{l}\text { Both teacher and } \\
\text { student have equal } \\
\text { responsibility in the } \\
\text { learning process. The } \\
\text { teacher plays the role of } \\
\text { the researcher. In } \\
\text { addition he has to } \\
\text { observe and get to } \\
\text { know his students, } \\
\text { thereby seeking } \\
\text { approaches to high } \\
\text { quality teaching. }\end{array}$ \\
\hline
\end{tabular}




\begin{tabular}{|c|c|c|c|}
\hline MISTAKE & $\begin{array}{l}\text { Mistake should be } \\
\text { avoided at all costs as it } \\
\text { is an obstacle in the } \\
\text { learning process. } \\
\text { Mistakes are indicators } \\
\text { of inefficient learning } \\
\text { and teaching. }\end{array}$ & $\begin{array}{l}\text { Mistakes don't have a } \\
\text { negative role as from } \\
\text { mistakes we learn. }\end{array}$ & $\begin{array}{l}\text { Mistakes define learning } \\
\text { and create new } \\
\text { opportunities for } \\
\text { learning. Since cognitive } \\
\text { conflicts are crucial for } \\
\text { learning and } \\
\text { reconstructing } \\
\text { knowledge mistakes are } \\
\text { welcome in the learning } \\
\text { process. }\end{array}$ \\
\hline \multirow{3}{*}{\begin{tabular}{|l|} 
\\
IMPLICATIONS \\
FOR \\
TEACHING \\
AND \\
LEARNING
\end{tabular}} & $\begin{array}{l}\text { Learning content should } \\
\text { be divided into smaller } \\
\text { parts. Smaller parts of } \\
\text { the learning content are } \\
\text { easier to master and } \\
\text { mistakes can be } \\
\text { avoided. It also enables } \\
\text { the teacher to give } \\
\text { immediate feedback. }\end{array}$ & $\begin{array}{l}\text { The student has to } \\
\text { understand and make } \\
\text { sense of the learning } \\
\text { content. }\end{array}$ & $\begin{array}{l}\text { In terms of quantity of } \\
\text { learning content, less is } \\
\text { more. }\end{array}$ \\
\hline & $\begin{array}{l}\text { Immediate feedback, } \\
\text { especially positive, is } \\
\text { crucial. }\end{array}$ & $\begin{array}{l}\text { The student's working } \\
\text { memory should not be } \\
\text { overloaded with too } \\
\text { much new information. }\end{array}$ & $\begin{array}{l}\text { The teacher uses a } \\
\text { variety of strategies and } \\
\text { creates the right } \\
\text { circumstances, in which } \\
\text { students can } \\
\text { independently construct } \\
\text { their knowledge and } \\
\text { reconstruct their } \\
\text { knowledge when the } \\
\text { situation of cognitive } \\
\text { conflict arises. }\end{array}$ \\
\hline & $\begin{array}{l}\text { Exercise and drill are } \\
\text { the most significant part } \\
\text { of the learning process. }\end{array}$ & $\begin{array}{l}\text { Exercise is important, } \\
\text { but it is essential for the } \\
\text { teacher to know WHEN } \\
\text { to exercise and HOW to } \\
\text { exercise. }\end{array}$ & $\begin{array}{l}\text { Every new learning } \\
\text { content or concept has } \\
\text { to be presented in } \\
\text { different ways with } \\
\text { different strategies as } \\
\text { every student learns in } \\
\text { his own way. }\end{array}$ \\
\hline
\end{tabular}

Sources: Batistič Zorec 2003, Driscoll 2000, Lightbown and Spada 2006, Maicusi and others 2000, Orlich and others 2001, Plut Pregelj 2008, Shuell 1986, Simons 1997, Woolfolk 2002

On the other hand when evaluating approaches to teaching and learning Chinese vocabulary we cannot evaluate the approaches from the perspective of behaviorism, cognitivism and constructivism only. We can divide the first teachers of CFL in the western countries into two pillars: Chinese immigrants living in the West and western missionaries working in China (Xing 2006). If western missionaries and later teachers of CFL based their approaches to teaching CFL on learning theories such as 
behaviorism, cognitivism and constructivism, Chinese immigrants based their approaches to teaching CFL on Chinese tradition, especially Confucianism.

We cannot say that Confucianism is a learning theory, but Confucianism has played an important role in the lives of the Chinese people throughout history as philosophy, religion, political ideology and moral doctrine (Rošker 2005, Yao 2000). Confucius was according to Cheng (1985) the first person in Chinese history to establish a private school and made education available to everybody. Confucianism is therefore closely related to education also.

Nevertheless as Confucianism is not a learning theory but rather a philosophy of humanity its key principles differ from the key principles of the three learning theories exposed in Table 1. Behaviorism, cognitivism and constructivism all focus on human behavior, mental processes, mental development and the student's selfactivity. Confucianism, in terms of education, does not deal with observing and researching human behavior and mental development, but focuses rather on the importance of moral education and transmission of knowledge (teaching the classics) (Rošker 2005, Yang 1993). Key principles of Confucian view on teaching and learning are shown in Table 2.

Table 2: Key principles of Confucian view on teaching and learning

\begin{tabular}{|l|l|}
\hline $\begin{array}{l}\text { NATURE VS. } \\
\text { NURTURE }\end{array}$ & $\begin{array}{l}\text { Understanding and learning already existing knowledge is the key to } \\
\text { changing individuals. We are all born equal. }\end{array}$ \\
\hline LEARNING & $\begin{array}{l}\text { Moral education and learning the classics are most important parts of } \\
\text { the learning process. The key is to internalize, understand and discuss } \\
\text { about already existing knowledge. }\end{array}$ \\
\hline $\begin{array}{l}\text { THE ROLE OF } \\
\text { THE STUDENT }\end{array}$ & $\begin{array}{l}\text { The student is respectful, disciplined, understands the importance of } \\
\text { community and does more listening than asking. }\end{array}$ \\
\hline $\begin{array}{l}\text { THE ROLE OF } \\
\text { THE TEACHER }\end{array}$ & $\begin{array}{l}\text { The teacher is a role model (especially in the terms of moral behavior) } \\
\text { and authority in the learning process. The teacher possesses extensive } \\
\text { knowledge and the student's role is to follow the teacher completely. }\end{array}$ \\
\hline MISTAKE & Mistakes should be avoided at all costs. \\
\hline $\begin{array}{l}\text { IMPLICATIONS } \\
\text { FOR TEACHING } \\
\text { AND LEARNING }\end{array}$ & Memorization, exercise and drill are vital parts of the learning process. \\
\hline
\end{tabular}

Sources: Li 2004, Wang 2011, Xia 2011, Xing 2006

According to Li (2004) there seems to be a belief that teaching and learning in China is based on memorization, exercise and drill and that these methods are in direct connection to the Confucian tradition. Xing (2006) names this method "the duckfeeding method", whereas Cai (2012) names it the "mouth-ear" method which clearly 
summarizes the key principles of this method shown in Table 2. But is the so-called "duck-feeding method" really in accordance with the original teachings of Confucius?

As Rošker (2005) points out Confucius emphasized the importance of internalizing the existing knowledge rather than independently think and search for new ideas. As far as Confucius was concerned all the important knowledge and truths already existed and thinking independently and searching for new truths was therefore completely inappropriate (ibid). Even though thinking independently was not appropriate Confucius still wanted his pupils to think and understand the already existing knowledge and not only memorize it (ibid). Thinking can therefore have good or bad consequences according to Confucius (ibid). If we only learn and don't understand what we have learnt, learning has no sense. But if we search for new knowledge and contemplate without possessing the right knowledge, learning becomes dangerous (ibid).

Li (2004) says that among the western stereotypes about learning according to Confucian tradition the stereotype that stands out is that the Chinese learning method is based on memorization. Li (ibid) explains that this is a stereotype because the Chinese way of memorizing is not only learning by heart but also includes understanding.

When relating memorization to the Confucian tradition both $\mathrm{Li}$ (2004) and Xia (2011) talk about an important period in China's history that has had a major impact on learning methods in China - the imperial examination. Historically the teachings of Confucian philosophers were the basis for all education in China, but especially the imperial examination system, and pupils and candidates for the state bureaucracy were forced to memorize their teachings and were never encouraged to think creatively about them (Li 2004). As Xia (2011) points out the students in China seem to be learning the so-called "silent English", since after ten years of learning most of the students are not able to use English in real life situations. Xia (ibid.) believes that this is related to the current Chinese examination system to enter the university, which has the same importance today as the imperial examination did in the past. As these exams are so important, the primary goal of the teachers, students and parents is to pass them. The only goal of learning English is therefore to pass the exam and not to use the language in real life.

All this shows that the teachings of Confucius are in a way contradictory as Confucius wanted his pupils to understand the knowledge, but on the other hand the pupils were supposed to understand the knowledge the right way and not in their own way. Maybe these contradictions could also lead to different authors interpreting the teachings of Confucius and Confucianism in two different ways.

Even though Li (2004), Shi (2006) and Shim (2008) assert that there is often a misguided view upon teaching and learning according to the original teachings of Confucius, there is still a general belief between authors like Cai (2012), Wang (2011), Xia (2011) and Xing (2006) that teaching in modern China is based on the "duck- 
feeding method" as Xing (2006) calls it. Maybe we could relate this inconsistency among the authors' beliefs with the following two arguments:

First, Li (2004) and Shim (2008) focus on the research of teaching English as a foreign language in China, which is definitely also under the influence of non-Chinese teachers and textbooks and can lead to a different point of view on teaching and learning. This point of view could combine the key principles of Confucianism and the key principles of teaching foreign languages in the West.

Second, Confucianism has more than 2000 years of tradition, during which it changed and adapted to current social, political and historical circumstances, which led to deviations from the original teachings of Confucianism as Milčinski (in Klasiki konfucijanstva 2005) points out. Li (2004), Shi (2006) and Shim (2008) all focus on the original teachings of Confucius in their researches, whereas other authors focus on Confucianism in general.

Regardless of this inconsistency among authors we can expose three main features of teaching and learning according to Confucianism:

1. big emphasis on moral education;

2. the teacher is the authority in the learning process;

3. big emphasis on memorization (whether it includes understanding or not).

In continuation we will take a closer look at how different approaches to teaching Chinese vocabulary and to teaching characters are related to different learning theories and to Confucianism.

\subsection{Evaluating approaches to teaching and learning Chinese vocabulary from the learning theories perspective and from the perspective of Confucian view on learning and teaching}

\subsubsection{The approach that first introduces pronunciation}

This approach is largely consistent with the key principles of behaviorist learning theory as behaviorism puts a big emphasis on teaching pronunciation and listening first (Lightbown \& Spada 2006, Yang 2006). The method that is based on the behaviorist learning theory is also the method that has left a big impact on teaching Chinese pronunciation; it is the audio linguistic method (Liao 2004). The basic learning goals of the audio linguistic method are mastering grammar and pronunciation (Lightbown \& Spada 2006, Melero Abadía 2000).

The key principles that both behaviorism and Confucianism share are:

- memorizing,

- exercise and drill are key for learning,

- teacher is the authority in the learning process and the student has to trust him and follow him. 
All the mentioned common principles are also the basic principles of the so-called "duck-feeding method", which is according to Cai (2012) and Xing (2006) the traditional Chinese method for teaching foreign languages. Since the duck-feeding method is the traditional Chinese method for teaching foreign languages it is no surprise that this method has consolidated itself also as one of the traditional methods to teaching CFL.

Nevertheless it is difficult to evaluate the approaches to teaching Chinese vocabulary from the perspective of Confucianism, since Confucianism did not and does not deal with the issue which is more important in regards to the content and in regards to what the structure of the teaching content needs to be for it to lead to high quality teaching. The approach that simultaneously introduces pronunciation and character is therefore also completely acceptable from the Confucian point of view.

However when speaking of learning Chinese characters, Li (2004) believes that the need to memorize Chinese characters when teaching and learning Chinese as a foreign language is closely related to learning Chinese as a mother tongue. Li (ibid) lists the following characteristics of learning Chinese as a mother tongue:

- memorizing Chinese characters;

- learning pinyin by reading and repeating;

- emphasizing the correct pronunciation of the tones.

As far as the content goes both approaches are acceptable from the Confucian point of view. But as far as the teaching method goes we can relate this approach to both behaviorism and Confucianism, since the textbooks that are in accordance with this approach follow the same basic principles:

- emphasis on pronunciation, the character is included but is not that important and there is no emphasis on the character's structure;

- teaching of pronunciation is very extensive with drills and exercises;

- emphasis on pinyin, which is almost more important than the character.

Among the textbooks that are in accordance to this approach are:

- Beginning Chinese (DeFrancis 1976a in 1976b),

- Chinese course 汉语教程 (Yang 2002).

\subsubsection{The approach that simultaneously introduces pronunciation and character}

Cognitivism and constructivism in comparison to behaviorism, which focuses on the transfer of knowledge, memorization and exercise and drills, focus on the very important concept of understanding the learning content and not merely memorizing it without understanding (Woolfolk 2002). The concept of understanding the learning content is reflected in the teaching of pronunciation and characters and in teaching Chinese words as a whole. 
Different manuals and textbooks written and published in the last decade with the goal to help facilitate learning and teaching pronunciation and characters are closely related to the key principles of cognitivism and constructivism. Among these manuals are:

- Learning Chinese Characters. A revolutionary new way to learn and remember the 800 most basic Chinese characters (Matthews and Matthews 2007),

- Remembering Simplified Hanzi 1 (Heisig and Richardson 2009),

- Key to Mastering Chinese Characters (Gu 2008) for teaching characters and

- Chinese Through Tone \& Color (Dummit 2008) for teaching tones.

Vermunt (1996) and Woolfolk (2002) explain that students use different learning strategies and not every approach and strategy is good for every student. All of the four mentioned manuals try to facilitate learning and teaching pronunciation and characters by using different strategies and approaches: the first two by using mnemonics to explain the character's structure, the last one by linking colors with tones in order to help the visual learning style students.

\subsubsection{The approach of not teaching characters}

The approach of not teaching characters could be closely linked to the Confucian tradition and the traditional "duck-feeding method" according to Xing (2006). As explained previously the teacher's role is according to Confucian tradition the most important one. Not teaching characters is completely admissible, because the student cannot learn characters by listening and following the teacher, but only by writing the characters again and again. Since the student can do this on his own he should do it independently outside of class (Li 2004, Xing 2006).

On the other hand the behaviorist learning theory emphasizes the importance of pronunciation and listening, yet leaving the students to learn characters independently is unacceptable since it can lead to many mistakes in the learning process and mistakes have to be avoided at all costs.

Interestingly both textbooks that are in accordance with the approach that first introduces pronunciation leave the decision of teaching characters or not to the teacher. Beginning Chinese (DeFrancis 1976a in 1976b) by containing two books, one completely in pinyin and one in characters, and Chinese course 汉语教程 (Yang 2002) by including pinyin until lesson number 30. What is even more interesting is that both books put more emphasis on the correct stroke order and very little on the structure, which means that there might be a connection between the "duck-feeding method" and the approach that introduces pronunciation first with little emphasis on the character's structure. 


\subsubsection{Teaching characters according to their frequency in usage or through radicals}

According to behaviorist view on teaching and learning one of the main characteristics is that listening and pronunciation come first. When including characters in the learning process they need to be subordinated to listening, which means that they have to be taught according to the listening dialogues.

Since for constructivism and cognitivism the key is to understand the structure I believe the key to high quality learning of Chinese characters is in finding a middle road between teaching by frequency and teaching through radicals. The simplest characters are usually the most frequent ones, but it is difficult to see and explain the structure due to the simplification process. But teaching through radicals alone means that many of the most frequent ones will be left out.

\section{Comparing the approaches to teaching chinese vocabulary: An experimental case study}

As I have exposed in the previous chapters the lack of general guidelines, the development of different learning theories and the influence of Confucian tradition have led to different approaches to teaching CFL in general and to teaching Chinese vocabulary. Due to the lack of researches in the field of how to teach Chinese vocabulary and Chinese word as a whole, I have carried out an experimental case study among students of CFL at the Faculty of Arts in the academic year 2011/2012 to find out which of the approaches to teaching Chinese vocabulary will lead to high quality learning.

The main purpose of the experimental case study was to compare two approaches to teaching Chinese vocabulary:

- the approach that first introduces pronunciation that is based on behaviorism and is partly related to the traditional Confucian duckfeeding method and teaches the characters according to their frequency in usage with the emphasis on stroke order and with no emphasis on character's structure (in continuation APPROACH 1);

- the approach that introduces pronunciation and characters simultaneously that is based on constructivist key principles and that puts a big emphasis on learning and understanding the character's structure in addition to the correct stroke order (in continuation APPROACH 2).

The comparison was carried out from two perspectives:

- quality of knowledge of Chinese vocabulary and

- the level of motivation of students. 
One of the main problems in the study of sinology at Ljubljana's Faculty of Arts is the high dropout rate in the first couple of months. In the academic year 2001/2002 50 students were enrolled in the first year of sinology and by the beginning of the second semester only 3 students were attending class from my personal experience. As Figure 1 shows the highest dropout rate in the last ten years was $81 \%$ in the academic year 2002/2003 and the lowest in 2006/2007 when the rate was 59\%.

Figure 1: Structural number of students ( $\mathrm{f} \%$ ) who have progressed from first to second year for the last ten years

\section{Transition from first to second year}

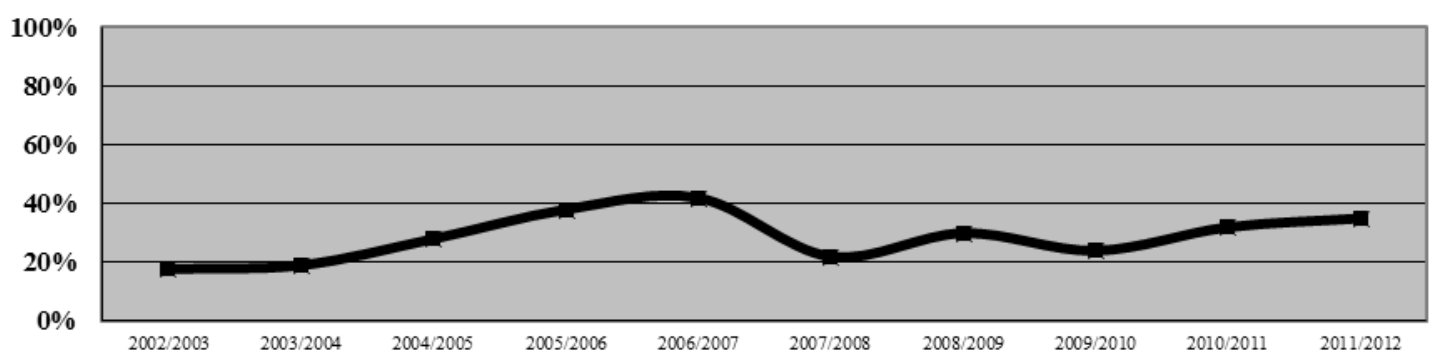

Source: Archive of the Department of Asian and African Studies, Faculty of Arts in Ljubljana

In addition to addressing the problem of the dropout rate and the quality of learning Chinese vocabulary, there is one more issue I wanted to address with the experimental case study, the use of pinyin. As explained previously focusing on pronunciation at the beginning can lead to students relying too much on pinyin and too little on characters. The use of pinyin when learning and teaching CFL is inevitable, but can a more subtle use of pinyin in the learning process facilitate learning how to write characters and read texts written in characters only?

\subsection{Research questions and research hypothesis}

On the basis of the previously mentioned main issues two main groups of research questions were addressed:

1. Motivation: will APPROACH 2 in comparison to APPROACH 1 lead to higher motivation, higher level of cooperation of students during the class and lower dropout rate?

2. Quality of knowledge: will APPROACH 2 in comparison to APPROACH 1 lead to higher quality of knowledge of Chinese vocabulary?

a. Pronunciation: since APPROACH 2 puts equal emphasis on learning and teaching of characters and pronunciation, will APPROACH 2 in comparison to APPROACH 1 lead to poorer knowledge of pronunciation and more mistakes in pronunciation? 
b. Character: will APPROACH 2 in comparison to APPROACH 1 facilitate the learning of writing and reading characters, lead to faster and easier recognition and learning of new and unknown characters? Since APPROACH 2 puts equal emphasis on learning and teaching of the character's structure and stroke order, will APPROACH 2 in comparison to APPROACH 1 lead to more mistakes in the stroke order?

c. Pinyin: will a more subtle use of pinyin in the learning process of APPROACH 2 in comparison to APPROACH 1 lead to higher focus on characters?

d. Word: will APPROACH 2 in comparison to APPROACH 1 facilitate the acquisition of Chinese words and vocabulary?

Research hypothesis:

1. Motivation: APPROACH 2 will lead to higher motivation, higher level of cooperation of students during the class and lower dropout rate in comparison to APPROACH 1.

2. Quality of knowledge: APPROACH 2 will lead to higher quality of knowledge of Chinese vocabulary in comparison to APPROACH 1.

a. Pronunciation: even though APPROACH 2 puts equal emphasis on learning and teaching of characters and pinyin, APPROACH 2 will not lead to poorer knowledge of pronunciation and more mistakes in pronunciation in comparison to APPROACH 1.

b. Character: APPROACH 2 will facilitate the learning of writing and reading characters, lead to faster and easier recognition and learning of new and unknown characters in comparison to APPROACH 1. Even though APPROACH 2 puts equal emphasis on learning and teaching of the character's structure and stroke order, APPROACH 2 will not lead to more mistakes in the stroke order in comparison to APPROACH 1.

c. Pinyin: more subtle use of pinyin in the learning process of the APPROACH 2 will lead to higher focus on characters in comparison to APPROACH 1.

d. Word: APPROACH 2 will facilitate the acquisition of Chinese words and vocabulary in comparison to APPROACH 1.

\subsection{Data and methodology}

The experimental case study was carried out by combining qualitative (observation, research diary, interview) and quantitative research methods (knowledge tests and attendance log) at the Faculty of Arts in the academic year 2011/2012. The decision of combining both qualitative and quantitative research methods was based on the following reasons: 
- because it is difficult to get a complete view on any phenomenon that includes people when using only quantitative research methods and

- because we can get a deeper view on the phenomena that include people by using qualitative research methods and a more complete view by using quantitative research methods (Vogrinc \& Devetak 2007).

According to Sagadin (1993) an experimental research is any research with two kinds of variables in which the researcher manipulates the independent variable (the approach to teaching and learning CFL in our case) and measures the dependent variables (dropout rate, level of cooperation of students during the classes, test results). Due to the fact that only approximately 30 students could be included in the study ${ }^{1}$ it is essential to call this experimental research an experimental case study. As Sagadin (1991) explains any research that focuses on certain course of study in certain academic year at certain school is consistent with a case study. The problem of a case study is that we cannot generalize the results to the underlying population, but according to Sagadin (ibid.) the results obtained in a case study can still be generalized to similar situations.

The experimental case study was carried out in the first semester (from October till end of January) since the first semester is crucial for building a good foundation when teaching and learning Chinese vocabulary.

33 students that were involved in the experimental case study were divided into two groups: control group (APPROACH 1) and experimental group (APPROACH 2). For the students to be able to attend all classes it was necessary to coordinate schedules and due to the coordination 21 students were enrolled in the control group and only 12 in the experimental as Table 3 shows.

Table 3: Division of students involved in the case study

\begin{tabular}{|l|c|c|}
\hline Group & $f$ & $f \%$ \\
\hline Control & 21 & $63,6 \%$ \\
\hline Experimental & 12 & $36,4 \%$ \\
\hline Total & 33 & $100 \%$ \\
\hline
\end{tabular}

Source: Simončič 2013, 236

\footnotetext{
${ }^{1}$ The Department of Asian and African studies in Ljubljana's Faculty of Arts is a department with three different courses of study: sinology, Japanese studies and studies of East Asian cultures. Each course of study enrolls approximately 30-40 students each year.
} 
Both control group and experimental group had in common:

- entrance level: all of the students were complete beginners;

- the teacher: the researcher was the teacher in both groups to avoid the influence of personal characteristics on the results;

- the curriculum.

What separated the control group from the experimental was:

- the approach:

○ the approach in the control group had the following characteristics:

- emphasis on pronunciation,

- emphasis on learning the correct stroke order of characters without the explanation of the character's structure,

- vocabulary was taught in accordance to the dialogues in the textbook and was therefore many times not related thematically,

- high use of pinyin,

- many exercises and drills,

- teacher was the authority, students followed the teacher.

o the approach in the experimental group had the following characteristics:

- equal emphasis on pronunciation and character,

- equal emphasis on character's structure and stroke order,

- vocabulary was taught thematically,

- subtle use of pinyin,

- exercises were varied, combined all four skills (listening, reading, writing, speaking) and were also carried out in pairs or groups,

- teacher was the mentor, students actively constructed their knowledge by constantly relating the new information to what they already knew.

- teaching material:

- teaching material in the control group was the textbook Chinese course 汉语教程 (Yang 2002),

- teaching material in the experimental group was prepared by the researcher according to the approach and to constructivist key principles. 


\subsection{Research methods}

Three basic research methods were used within qualitative research.

\subsubsection{Observation}

According to different types of observation that Vogrinc (2008) presents the observation in this experimental case study was:

- scientifical, because it was preplanned and goal oriented;

- public, because the students were aware of it from the beginning;

- with participation, because the researcher was an active part of the group although the role of the researcher was different than the role of the students;

- $\quad$ partly structured, because the observation logs scheme was prepared in advance, but the scheme still allowed changes to be made if the need arose.

Observation logs were prepared by the researcher according to the research problem, research questions and hypothesis. The main objectives considered during the preparation of the observation logs scheme were motivation and the quality of knowledge. Within these two, cooperation during the class, quality of pronunciation and writing characters were also considered.

\subsubsection{Research diary}

Research diary was used to record all the data that was not recorded within the observation logs.

\subsubsection{Interview}

Based on the characteristics of the unstandardized interview that Vogrinc (ibid) explains, the decision was made to use an unstandardized interview, because:

- it is a less formal, more open and flexible type of interview;

- only the main goal of the interview is preset, the researcher can change the content and sequence of questions according to the situation;

- the relationship between the researcher and the interviewee is more personal.

I interviewed 6 students, three from each group with similar results on the 4 tests and above average attendance logs and posed them 11 different questions referring mainly to their opinion about the classes, textbooks and learning activities.

Apart from attendance logs, there were 4 knowledge tests and 1 test prepared especially to test the capability of students to conclude the meaning and pronunciation of unknown characters and words to research the quality of knowledge of Chinese vocabulary used within quantitative research. 
All four knowledge test were part of a formal examination and had the same assessment criteria. The tests contained from six to nine different tasks that tested the knowledge of different language skills based on the learning content: listening comprehension, reading comprehension and written expression. Only the content of the especially prepared test which was not part of a formal examination, but was prepared for the purposes of the experimental case study only, was different from the 4 knowledge tests. As this test was used to test the capability of students to conclude the meaning and pronunciation of unknown characters and words, it did not directly test what the students learned during the year, but whether they can actively transfer the acquired knowledge about the structure of Chinese characters and words to new and unknown Chinese characters and words.

According to Sagadin's (1993) important measure characteristics of knowledge tests, which include validity, reliability, objectivity and sensitivity, I defined the measure characteristics of all five tests. I determined the validity by using rational and empirical validation, reliability by using Cronbach's alfa and sensitivity by determining the difficulty index and the index of discrimination for all five tests. Objectivity was ensured by uniform criteria and objective testing circumstances.

\subsection{Key findings}

Although the sample was very small, I have come to some basic empirical findings based on the following research methods:

- attendance logs for dropout rate,

- observation logs for motivation, level of cooperation during classes and the use of pinyin and characters when doing exercises and making notes,

- interviews for motivation,

- four knowledge tests and one test prepared especially to test the capability of students to conclude the meaning and pronunciation of unknown characters and words.

\subsubsection{Attendance analysis}

As Figure 2 shows the dropout rate in the experimental group was lower (67\%) than in the control group, since by the end of the year only $19 \%$ of the students of control group were still attending class, which means that the dropout rate in the control group was $81 \%$. According to the attendance log chart the attendance was higher in both groups when mandatory tests were on schedule, yet the difference is even higher in the control group. This could mean that the students of the control group were not motivated enough to attend classes, but they studied independently and only attended classes when mandatory tests were on schedule. 
Figure 2: Attendance log chart for both groups

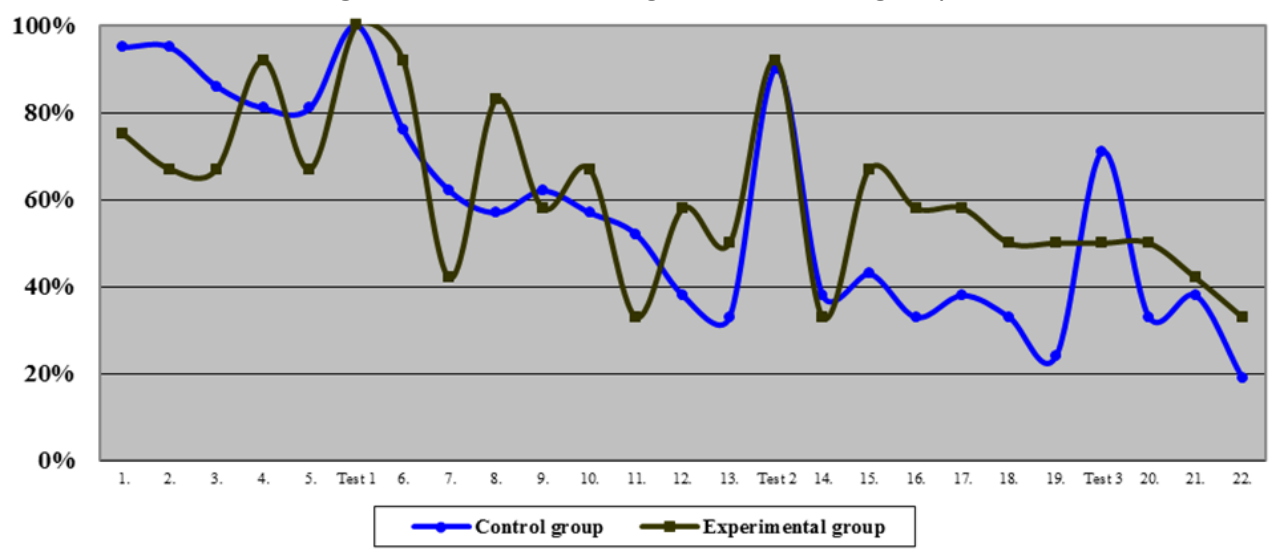

Source: Simončič 2013, 313

On the other hand we can say that for the experimental group a big difference between attending classes and tests is only seen at the time of the second test. In addition we can see that, with the exception of the classes with tests, the dropout line in the control group is much more steady than in the experimental group which means that the students of the control group were slowly dropping out one after another (by the end of the year only $4 \%$ of the students of the control group were still attending classes) in comparison to the students of the experimental group whose dropout rate even lowered in the second semester ${ }^{2}$.

\subsubsection{Analysis of motivation and level of cooperation during the class}

Observation logs and interview were the key research methods for analyzing motivation and level of cooperation during the class. The content of the observation logs was divided into 9 parts, of which part 2 was intended for observing the level of cooperation and motivation during the class and included 5 observation points (signs of boredom, posing questions and presenting ideas, focusing on the content and the level of relaxation).

Based on the analysis and comparison of part 2 of the observation logs from the experimental and control group, the students od the experimental group were more motivated to cooperate actively with many additional questions and ideas during the class, whereas the students of the control group were only listening and had practically no additional questions. For both groups the level of motivation and cooperation was very high at the beginning (first six lessons) and for both groups it was characteristic that there were certain lessons when the level of motivation and cooperation was lower. Nevertheless I did not detect drastic drops of motivation and cooperation level in the experimental group whereas the students of the control group many times showed signs of boredom (yawning, chatting etc.).

\footnotetext{
${ }^{2}$ Based on the attendance logs for the second semester.
} 
In addition, through the process of coding interview responses, which included 11 questions prepared specifically to find out the level of motivation of the students, the answers of 6 students questioned in the interview (3 from the control group and 3 from the experimental) showed that the students of the experimental group believed that the innovative approach helped them to understand the structure of the characters, motivated them to cooperate, attend classes and learn Chinese outside the class.

\subsubsection{Quality of knowledge}

Statistical analysis of the results of both groups on 4 knowledge tests and 1 test prepared especially to test the capability of students to conclude the meaning and pronunciation of unknown characters and words gave the following results:

\section{Pronunciation}

To test the quality of knowledge of pronunciation the students wrote 3 dictations. Table 4 shows the results of F-test and t-test of differences in total score of the three dictations.

Table 4: Results of F-test and t-test of differences in total score on three dictations

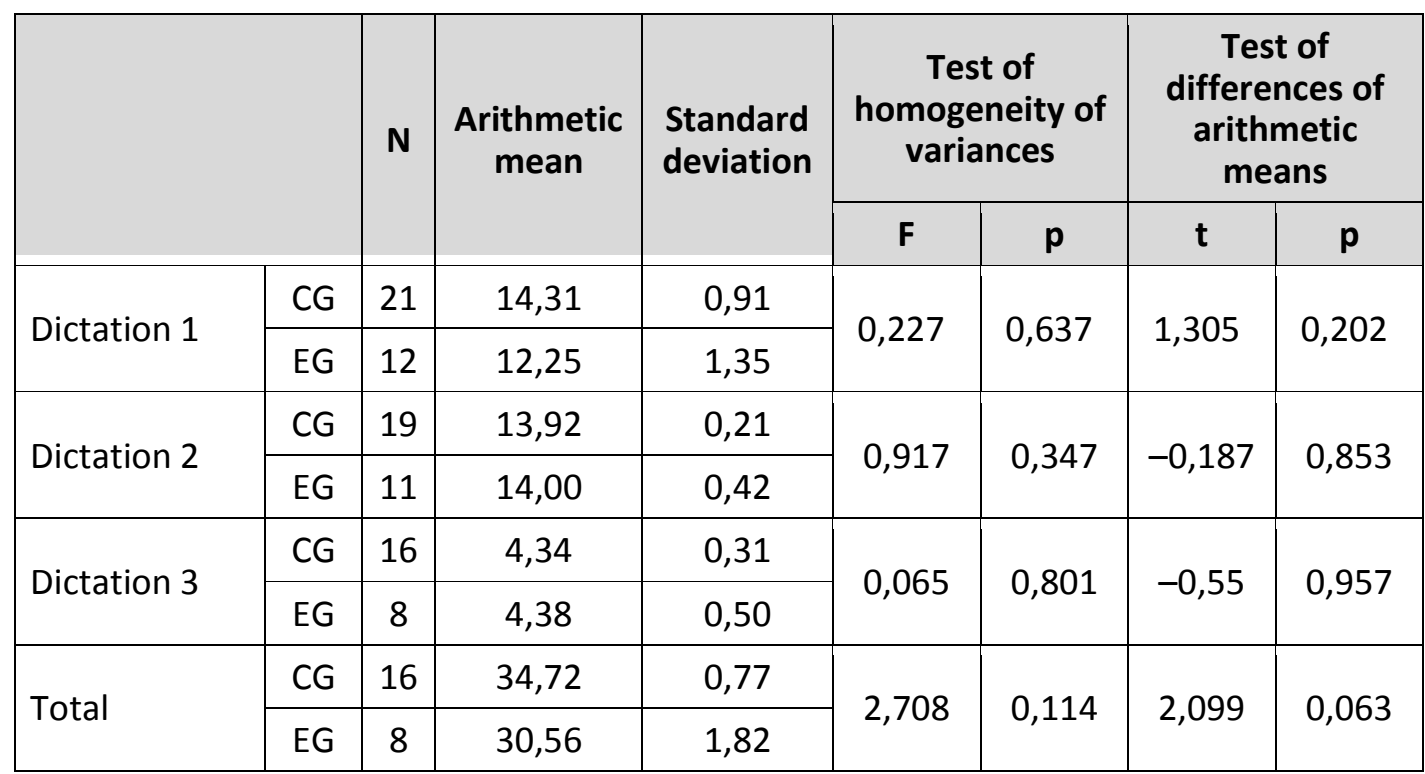

Source: Simončič 2013, 350

The results of the F-test show that there are no statistically important differences in variances $(F=0,403 ; p=0,595)$. The results of the t-test also show that between the two groups in the three dictations there are no statistically significant differences 
$(t=2.099 ; p=0.063)$. The statistical analysis of the results on all 3 dictations therefore shows that there were no statistically important differences between both groups, which means that even though APPROACH 2 put equal emphasis on pronunciation and characters the results of the students in the experimental group were not poorer.

\section{Characters}

To test the quality of knowledge of characters 2 different types of test tasks were prepared within the especially prepared test: ones to test the correct stroke order and ones to test the knowledge of character's structure.

Table 5: Results of F-test and t-test of differences in total score on tasks that test the knowledge of the structure of characters tested within the especially prepared test

\begin{tabular}{|c|c|c|c|c|c|c|c|c|}
\hline & & \multirow[t]{2}{*}{$\mathbf{N}$} & \multirow[t]{2}{*}{$\begin{array}{c}\text { Arithmetic } \\
\text { mean }\end{array}$} & \multirow[t]{2}{*}{$\begin{array}{l}\text { Standard } \\
\text { deviation }\end{array}$} & \multicolumn{2}{|c|}{$\begin{array}{c}\text { Test of } \\
\text { homogeneity } \\
\text { of variances }\end{array}$} & \multicolumn{2}{|c|}{$\begin{array}{l}\text { Test of } \\
\text { differences of } \\
\text { arithmetic } \\
\text { means }\end{array}$} \\
\hline & & & & & $\mathbf{F}$ & p & $t$ & $p$ \\
\hline \multirow{2}{*}{$\begin{array}{l}\text { Capability test } \\
\text { task } 1\end{array}$} & $\mathrm{CG}$ & 16 & 1,88 & 0,38 & \multirow{2}{*}{3,819} & \multirow{2}{*}{0,064} & \multirow{2}{*}{$-2,66$} & \multirow{2}{*}{0,015} \\
\hline & EG & 6 & 4,33 & 1,15 & & & & \\
\hline \multirow{2}{*}{$\begin{array}{l}\text { Capability test } \\
\text { task } 2\end{array}$} & CG & 16 & 2,06 & 0,52 & \multirow{2}{*}{4,978} & \multirow{2}{*}{0,037} & \multirow{2}{*}{$-1,134$} & \multirow{2}{*}{0,27} \\
\hline & EG & 6 & 3,50 & 1,61 & & & & \\
\hline \multirow{2}{*}{ Total } & CG & 16 & 3,94 & 0,77 & \multirow{2}{*}{6,686} & \multirow{2}{*}{0,017} & \multirow{2}{*}{$-1,964$} & \multirow{2}{*}{0,043} \\
\hline & EG & 6 & 7,83 & 2,61 & & & & \\
\hline
\end{tabular}

Source: Simončič 2013, 357

Both the results of the F-test and t-test show that there are statistically significant differences on the total score of the two tasks prepared to test the knowledge of the structure of characters $(F=6,686 ; p=0,017 ; t=-1,964 ; p=0,043)$, which means that we can assert that the APPROACH 2, which put more emphasis on the structure of characters and that was based on the key principles of the constructivist learning theory, helped the students of the experimental group achieve better results on tasks that tested the knowledge of the structure of characters. 
Table 6: Results of F-test and t-test of differences in total score on tasks that test the knowledge of the correct stroke order of characters tested within the especially prepared test

\begin{tabular}{|c|c|c|c|c|c|c|c|c|}
\hline & & \multirow[t]{2}{*}{$\mathbf{N}$} & \multirow[t]{2}{*}{$\begin{array}{l}\text { Arithmetic } \\
\text { mean }\end{array}$} & \multirow[t]{2}{*}{$\begin{array}{l}\text { Standard } \\
\text { deviation }\end{array}$} & \multicolumn{2}{|c|}{$\begin{array}{c}\text { Test of } \\
\text { homogeneity } \\
\text { of variances }\end{array}$} & \multicolumn{2}{|c|}{$\begin{array}{l}\text { Test of } \\
\text { differences of } \\
\text { arithmetic } \\
\text { means }\end{array}$} \\
\hline & & & & & $\mathbf{F}$ & $\mathbf{p}$ & $\mathbf{t}$ & $\mathbf{p}$ \\
\hline \multirow{2}{*}{$\begin{array}{l}\text { Task } \\
\text { (stroke order) } 1\end{array}$} & CG & 21 & 8,88 & 0,36 & \multirow{2}{*}{0,137} & \multirow{2}{*}{0,714} & \multirow{2}{*}{1,395} & \multirow{2}{*}{0,173} \\
\hline & EG & 12 & 8,08 & 0,41 & & & & \\
\hline \multirow{2}{*}{$\begin{array}{l}\text { Task } \\
\text { (stroke order) } 2\end{array}$} & CG & 19 & 7,92 & 0,28 & \multirow{2}{*}{5,521} & \multirow{2}{*}{0,056} & \multirow{2}{*}{0,874} & \multirow{2}{*}{0,39} \\
\hline & EG & 11 & 7,25 & 0,93 & & & & \\
\hline \multirow{2}{*}{$\begin{array}{l}\text { Task } \\
\text { (stroke order) } 3\end{array}$} & CG & 16 & 4,16 & 0,17 & \multirow{2}{*}{0,18} & \multirow{2}{*}{0,675} & \multirow{2}{*}{0,514} & \multirow{2}{*}{0,613} \\
\hline & EG & 8 & 4,00 & 0,25 & & & & \\
\hline \multirow{2}{*}{ Total } & CG & 16 & 21,69 & 0,51 & \multirow{2}{*}{0,031} & \multirow{2}{*}{0,861} & \multirow{2}{*}{1,121} & \multirow{2}{*}{0,274} \\
\hline & EG & 8 & 20,69 & 0,75 & & & & \\
\hline
\end{tabular}

Source: Simončič 2013, 358

On the other hand both the results of the F-test and t-test show that there are no statistically important differences on the total score of the three tasks prepared to test the knowledge of the correct stroke order $(F=0,031 ; P=0,861 ; t=1,121 ; P=$ $0,274)$.

To resume, even though APPROACH 2 put equal emphasis on stroke order and characters' structure in contrast to APPROACH 1, which only put emphasis on the correct stroke order, the students of the experimental group did not achieve poorer results on the correct stroke order test types. Nevertheless the analysis of the test types testing the knowledge of a characters' structure showed that students of the experimental group were statistically better at knowing and recognizing the character's structure.

\section{Pinyin}

Pinyin was present in the control group during the whole period of the experimental case study as all the dialogues and some of the exercises in the textbook Chinese course 汉语教程 (Yang 2002), the textbook that was used in the control group, include pinyin until lesson number 30 . The fact that all the dialogues are also written in pinyin means that the students didn't actually have to know the characters to be able to read the dialogues.

To see if a more subtle use of pinyin contributed to higher focus on character, meaning that the students of the experimental group would have less trouble when reading texts written in characters only and would use characters instead of pinyin 
even when writing or solving exercises independently, part 8 of the observations logs was intended to observe the use of pinyin during the class.

The analysis of part 8 of the observation logs of both groups showed that students of the experimental group used characters instead of pinyin even when making notes and doing exercises whereas the students of the control group used and relied mostly on pinyin. Since pinyin was used only as a bridge between pronunciation and character in the experimental group and not as key element of teaching Chinese words the students of the experimental group did not rely on pinyin.

\section{Words and vocabulary}

There were altogether 8 tasks that tested the knowledge of vocabulary on the five tests. The tasks within the four formal test tested general knowledge of vocabulary learned during the classes. But the tasks prepared within the test prepared especially to test the capability of students to conclude the meaning and pronunciation of unknown characters and words were different as these tasks included only the characters and words that the students have not learned yet, but should be able to conclude their general meaning based on knowing the structure of the characters.

Table 7: Results of F-test and t-test of differences in total score on tasks that test the knowledge of vocabulary

\begin{tabular}{|c|c|c|c|c|c|c|c|c|}
\hline & & \multirow[t]{2}{*}{$\mathbf{N}$} & \multirow[t]{2}{*}{$\begin{array}{l}\text { Arithmetic } \\
\text { mean }\end{array}$} & \multirow[t]{2}{*}{$\begin{array}{l}\text { Standard } \\
\text { deviation }\end{array}$} & \multicolumn{2}{|c|}{$\begin{array}{c}\text { Test of } \\
\text { homogeneity } \\
\text { of variances }\end{array}$} & \multicolumn{2}{|c|}{$\begin{array}{l}\text { Test of } \\
\text { differences of } \\
\text { arithmetic } \\
\text { means }\end{array}$} \\
\hline & & & & & $\mathbf{F}$ & $p$ & $\mathbf{t}$ & $p$ \\
\hline \multirow{2}{*}{$\begin{array}{l}\text { Task } \\
\text { (vocabulary) } 1\end{array}$} & CG & 21 & 5,21 & 0,18 & \multirow{2}{*}{4,77} & \multirow{2}{*}{0,037} & \multirow{2}{*}{1,626} & \multirow{2}{*}{0,114} \\
\hline & EG & 12 & 4,54 & 0,45 & & & & \\
\hline \multirow{2}{*}{$\begin{array}{l}\text { Task } \\
\text { (vocabulary) } 2\end{array}$} & CG & 19 & 5,26 & 0,66 & \multirow{2}{*}{0,195} & \multirow{2}{*}{0,662} & \multirow{2}{*}{0,644} & \multirow{2}{*}{0,525} \\
\hline & EG & 11 & 4,50 & 1,06 & & & & \\
\hline \multirow{2}{*}{$\begin{array}{l}\text { Task } \\
\text { (vocabulary) } 3\end{array}$} & CG & 15 & 2,20 & 0,14 & \multirow{2}{*}{1,263} & \multirow{2}{*}{0,275} & \multirow{2}{*}{$-0,553$} & \multirow{2}{*}{0,587} \\
\hline & EG & 6 & 2,33 & 0,11 & & & & \\
\hline \multirow{2}{*}{$\begin{array}{l}\text { Task } \\
\text { (vocabulary) } 4\end{array}$} & CG & 15 & 8,91 & 1,60 & \multirow{2}{*}{0,005} & \multirow{2}{*}{0,947} & \multirow{2}{*}{$-0,079$} & \multirow{2}{*}{0,938} \\
\hline & EG & 6 & 9,12 & 2,28 & & & & \\
\hline \multirow{2}{*}{ Total } & CG & 15 & 22,43 & 1,85 & \multirow{2}{*}{0,846} & \multirow{2}{*}{0,369} & \multirow{2}{*}{0,057} & \multirow{2}{*}{0,955} \\
\hline & $\mathrm{EG}$ & 6 & 22,25 & 1,95 & & & & \\
\hline
\end{tabular}




\begin{tabular}{|c|c|c|c|c|c|c|c|c|}
\hline & & \multirow[t]{2}{*}{$\mathbf{N}$} & \multirow[t]{2}{*}{$\begin{array}{l}\text { Arithmetic } \\
\text { mean }\end{array}$} & \multirow[t]{2}{*}{$\begin{array}{l}\text { Standard } \\
\text { deviation }\end{array}$} & \multicolumn{2}{|c|}{$\begin{array}{c}\text { Test of } \\
\text { homogeneity of } \\
\text { variances }\end{array}$} & \multicolumn{2}{|c|}{$\begin{array}{c}\text { Test of } \\
\text { differences of } \\
\text { arithmetic } \\
\text { means }\end{array}$} \\
\hline & & & & & $\mathbf{F}$ & $\mathbf{p}$ & $\mathbf{t}$ & $\mathbf{p}$ \\
\hline \multirow{2}{*}{$\begin{array}{l}\text { Capability test } \\
\text { (vocabulary) task } 3\end{array}$} & CG & 16 & 2,47 & 0,32 & \multirow{2}{*}{1,267} & \multirow{2}{*}{0,273} & \multirow{2}{*}{$-1,438$} & \multirow{2}{*}{0,165} \\
\hline & EG & 6 & 3,50 & 0,81 & & & & \\
\hline \multirow{2}{*}{$\begin{array}{l}\text { Capability test } \\
\text { (vocabulary) task } 4\end{array}$} & CG & 16 & 2,24 & 0,47 & \multirow{2}{*}{8,938} & \multirow{2}{*}{0,007} & \multirow{2}{*}{$-3,018$} & \multirow{2}{*}{0,007} \\
\hline & EG & 6 & 5,67 & 1,41 & & & & \\
\hline \multirow{2}{*}{$\begin{array}{l}\text { Capability test } \\
\text { (vocabulary) task } 5\end{array}$} & CG & 16 & 3,12 & 0,33 & \multirow{2}{*}{11,535} & \multirow{2}{*}{0,003} & \multirow{2}{*}{$-2,055$} & \multirow{2}{*}{0,05} \\
\hline & EG & 6 & 5,17 & 1,45 & & & & \\
\hline \multirow{2}{*}{$\begin{array}{l}\text { Capability test } \\
\text { (vocabulary) task } 6\end{array}$} & CG & 16 & 1,35 & 0,31 & \multirow{2}{*}{1,983} & \multirow{2}{*}{0,174} & \multirow{2}{*}{$-2,836$} & \multirow{2}{*}{0,01} \\
\hline & EG & 6 & 3,50 & 0,96 & & & & \\
\hline \multirow{2}{*}{ Total } & CG & 16 & 9,18 & 0,86 & \multirow{2}{*}{10,141} & \multirow{2}{*}{0,004} & \multirow{2}{*}{$-2,596$} & \multirow{2}{*}{0,016} \\
\hline & $\mathrm{EG}$ & 6 & 30,57 & 13,098 & & & & \\
\hline
\end{tabular}

Source: Simončič 2013, 367-368.

Even though the results of the F-test and t-test show that there are no statistically important differences between both groups on tasks that were testing general knowledge of vocabulary $(F=0,846 ; p=0,369 ; t=0,057 ; p=0,955)$, the results of the F-test and t-test show that there are statistically important differences between both groups on tasks that were testing the capability of students to conclude the meaning and pronunciation of unknown characters and words $(F=10,141 ; p=0,004 ; t=-$ $2,596 ; p=0,016)$. The statistical analysis of the test types testing the knowledge of unknown words and vocabulary therefore shows that the students of the experimental group were much more aware of the structure of characters and were able to deduct the meaning and pronunciation of new and unknown characters with the help of their previous knowledge of the structure of characters.

To resume the results showed that the students that learned by the approach that simultaneously introduces pronunciation and character and is based on constructivist learning theory were much more aware of the structure of characters, more focused on the characters, did not rely on pinyin and used characters even when writing on their own. Not only were the students of the experimental group more aware of the words' general structure and were more able to deduct the meaning and pronunciation of new and unknown words based on their knowledge of the words' structure; they were more motivated to attend classes, pose questions, cooperate during class and continue learning CFL. 


\section{Research contribution}

When talking about implementing a new innovative approach to teaching and learning Chinese language that is based on constructivist principles I believe the experimental case study has shown that the key is for students to construct the knowledge of Chinese words and not to memorize it.

However when talking about implementing a new innovative approach to teaching Chinese language into Slovenian schools there are several issues that need to be addressed:

- The aversion of teachers, especially those of Chinese heritage in my personal experience, toward implementing innovative approaches, which can be related to the Confucian tradition.

- There are no relevant teaching materials that would attract and motivate Slovenian students.

- For the teachers to be able to implement such approach they need to be properly educated and guided through this process (Driscoll 2000).

- In order to implement innovative approach the teachers, schools and organizations have to be prepared to fully commit to it (Korthagen and Vasalos 2005, Resnick and others 2013).

The advantage that the Chinese language has is simply the fact that Chinese language is so different than other foreign languages taught in Slovenian schools. But in order to really motivate the students to learn Chinese, the approach to teaching and learning Chinese language has to be carefully selected.

Since teaching CFL is becoming more and more popular in Slovenian schools the key findings of the experimental case study can lead to higher quality learning of CFL and the development of high quality Slovenian textbooks for teaching CFL. Carefully prepared textbooks on the basis of the constructivist principles, properly educated teachers of CFL, the support of schools and organizations can lead to even higher number of learners of CFL not only in Slovenia but in the world.

\section{References}

Abraham, W. (2005). Chinese for Dummies. Indianapolis: Wiley Pub.

Batistič Zorec, M. (2003). Razvojna psihologija in vzgoja v vrtcih [Developmental Psychology and Education in Kindergartens]. Ljubljana: Inštitut za psihologijo osebnosti.

Cai, C. (2012). Reflections on Teaching Method of Discussion in Senior Public Servants Training. Network of Asia-Pacific Schools and Insitutes of Public Administration and Governance. Retrieved from [http://www.napsipag.org/PDF/CAI_CHUNHONG.pdf ], August 2012. 
Cheng, H. L. (1985). Confucianism and Zen. Journal of Chinese Philosophy, 12, 197-215.

Cui, X. (2010). 对外汉语教学名师访谈录 [Records of Conversation with Master of Teaching CFL]. Beijing: Beijing Language and Culture University Press. Retrieved from [http://ccbs.ntu.edu.tw/FULLTEXT/JR-JOCP/jc26595.htm\#16], August 2010.

DeFrancis, J. (1976a). Beginning Chinese. New Heaven and London: Yale University Press.

DeFrancis, J. (1976b). Character Text for Beginning Chinese. New Heaven and London: Yale University Press.

Driscoll, M. P. (2000). Psychology of Learning for Instruction. Boston: Allyn and Bacon.

Dummit, N. (2008). Chinese through Tone \& Color. New York: Hippocrene Books.

Everson, M. E. (2009). The Importance of Standards. In M. E., Everson \& Y., Xiao (eds.). Teaching Chinese as a Foreign Language. Theories and applications (pp. 3-18). Boston: Cheng \& Tsui Company.

Fletcher, J. D. (2008). From Behaviorism to Constructivism. A Philosophical journey from Drill and Practice to Situated Learning. In S. Tobias \& T. M. Duffy (eds.). Constructivist Instruction. Success or Failure?(pp. 242-263). New York: Routledge. Retrieved from [http://www.google.si/books?hl=sl\&|r=\&id=OPA_ZaCGU5gC\&oi=fnd\&pg=PP1\&dq=co nstructivist+instruction+success+or+failure \&ots=X70dLdIT_s\&sig=IYPk1k3_stpXtZooE 09o-oAT-

R4\&redir_esc=y\#v=onepage\&q=constructivist\%20instruction\%20success\%20or\%20fa ilure\&f=false], February 2012.

Gu, J. (2008). Key to Mastering Chinese Characters. Singapore: EPB Pan Pacific.

Heisig, J. W. \& Richardson, T. W. (2009). Remembering Simplified Hanzi 1. Honolulu: University of Hawai'i Press.

Jesenovec, M. (2004). Poučevanje, učenje in pomnjenje leksike drugega tujega jezika [Teaching, Learning and Memorizing the Vocabulary of a Foreign Language]. Jezik in slovstvo, 3/4, 35-47. Retrieved from

[http://www.dlib.si/dLib.si_v2/HTMLViewer.aspx?URN=URN:NBN:SI:doc-V8FQIBCS], March 2009.

Klasiki konfucijanstva - Štiri knjige: Konfucij, Mencij, Nauk o sredini, Veliki nauk. [Classics of Confucianism - Four Books: Confucius, Mencius, The doctrine of the mean, The great learning.] Trans. Milčinski, M. (2005). Ljubljana: Mladinska knjiga.

Korthagen, F. and Vasalos, A. (2005). Levels in Reflection: Core Reflection as a Means to Enhance Professional Growth. Teachers and Teaching: theory and practice, 11 (1), 4771.

Lai, J. (2006). Complete Mandarin Chinese. New York: Living Language.

$\mathrm{Li}, \mathrm{X}$. (2004). An analysis of chinese EFL learners' beliefs ebout the role of rote learning in vocabulary learning strategies. A thesis submitted in fulfilment of the requirements of the University of Sunderland for the degree of Doctor of Philosophy. Retrieved from [http://www.asian-efl-journal.com/xiuping_11-05_thesis.pdf], August 2012. 
Liao, X. (2004). The need for Communicative Language Teaching in China. ELT Journal, 58, 270-273. Retrieved from [http://eltj.oxfordjournals.org/cgi/reprint/58/3/270], March 2009.

Lightbown, P. M. \& Spada, N. (2006). How Languages are Learned. Oxford: Oxford University Press.

Lü, C. (2006). The Effects of Word-Knowledge Depth, Part of Speech, and Proficiency Level on Word Association Among Learners of Chinese as a Second Language. In M. E., Everson \& H. H., Shen (eds.). Research Among Learners of Chinese as a Foreign Language (pp. 67-92). University of Hawai'i at Mānoa: National Foreign Language Resource Center.

Maicusi, T., Maicusi, P., Carrillo López, M. J. (2000). The error in the Second Language Acquisiton. Encuentro. Revista de investigación e innovación en la clase de idiomas, 11, 168-173. Retrieved from [http://www.encuentrojournal.org/textos/11.17.pdf ], July 2012.

Marentič Požarnik, B. (2008). Konstruktivizem na poti od teorije spoznavanja do vplivanja na pedagoško razmišljanje, raziskovanje in učno prakso [Constructivism on the Way from Theory of Cognition to Influencing Educational Thinking, Researching and Teaching Practice]. Sodobna pedagogika, 59 (4), 28-51.

Matthews, A. \& Matthews, L. (2007). Learning Chinese Characters. A revolutionary new way to learn and remember the 800 most basic Chinese characters. Singapore: Tuttle Publishing.

Melero Abadía, P. (2000). Métodos y enfoques en la enseñanza/aprendizaje del ELE [Methods and Approaches to Teaching / Learning Spanish as a Foreign Language]. Madrid: Edelsa.

Orlich, D. C., Harder, R. J., Callahan, R. C., Trevisan, M. S., Brown, A. H. (2001). Teaching Strategies. A Guide to Effective Instruction. Boston: Houghton Mifflin Company.

Plut Pregelj, L. (2008). Ali so konstruktivistične teorije učenja in znanja lahko osnova za sodoben pouk? [Can Conconstructivist Learning Theories be the Basis for Modern Teaching?] Sodobna pedagogika, 59 (4), 14-27.

Resnick, L. B., Spillane, J. P., Goldman, P., Rangel, E. S. (2013). Uvajanje inovacij: od vizionarskih modelov do vsakodnevne prakse [Implementing Innovations: from Visionary Models to Everyday Practice]. In H., Dumont, D., Istance, F., Benavides (eds.). O naravi učenja: uporaba raziskav za navdih prakse (pp. 257-284). Ljubljana: Zavod Republike Slovenije za šolstvo.

Rošker, J. (2005). Iskanje poti: Spoznavna teorija v kitajski tradiciji [Finding the Way: Theory of Knowledge in the Chinese Tradition]. Ljubljana: Znanstveni inštitut Filozofske fakultete.

Sagadin, J. (1991). Razprave iz pedagoške metodologije [Discussions in Pedagogical Methodology]. Ljubljana: Znanstveni inštitut Filozofske fakultete Univerze v Ljubljani. 
Sagadin, J. (1993). Poglavja iz metodologije pedagoškega raziskovanja [Topics in the Methodology of Educational Research]. Ljubljana: Zavod Republike Slovenije za šolstvo in šport.

Shi, L. (2006). The Successors to Confucianism or a New Generation? A Questionnaire Study on Chinese Students' Culture of Learning English. Language, culture and curriculum, 1, 122-140. Retreived from [http://elechina.super-red.es/shi.pdf], August 2012.

Shim, S. H. (2008). A philosophical investigation of the role of teachers: A synthesis of Plato, Confucius, Buber, end Freire. Teaching and Teacher Education, 24, 515-535. Retreived from [http://cpdee.ufmg.br/ palhares/SHIMA\%20philosophical\%20investigation\%20of\%20the\%20role\%20of\%20teachers.pdf], August 2012.

Shuell, T. J. (1986). Cognitive Conceptions of Learning. Review od Educational Research, 4, 411-436.

Simončič, K. (2013). Ovrednotenje pristopov k poučevanju in učenju kitajskega besedišča z vidika teorij učenja: doktorska disertacija [Evaluating approaches to teaching and learning Chinese vocabulary from the learning theories perspective: doctoral dissertation]. Ljubljana: Filozofska fakulteta

Simons, P. R. J. (1997). Definitions and Theories of Active Learning. In D., Stern \& G. L. Huber (eds.). Active Learning for Students and Teachers, Reports from Eight Countries OECD (pp. 19-39). Frankfurt am Main: Peter Lang.

Skela, J. (2008). Vrednotenje učbenikov angleškega jezika z vidika kognitivne teorije učenja [Evaluating English Language Textbooks from the Perspective of Cognitive Learning Theory]. In Skela, J. (ed.) (2008). Učenje in poučevanje tujih jezikov na Slovenskem (pp. 154-178). Ljubljana: Založba Tangram.

Ur, P. (1996). A Course in Language Teaching. Cambridge: Cambridge University Press.

Vermunt, J. D. (1996). Metacognitive, cognitive and affective aspects of learning styles and strategies: A phenomenographic analysis. Higher Education, 31, 25-50.

Vogrinc, J. (2008). Kvalitativno raziskovanje na pedagoškem področju. Ljubljana: Pedagoška fakulteta. Dostopno na: http://pefprints.pef.uni-lj.si/179/1/Vogrinc1.pdf (pridobljeno 5. 9. 2012).

Vogrinc, J. \& Devetak, I. (2007). Ugotavljanje učinkovitosti uporabe vizualizacijskih elementov pri pouku naravoslovja s pomočjo pedagoškega raziskovanja [Researching the Effectiveness of the Use of Visualization Tools when Teaching Science with the Help of Educational Research]. In I. Devetak (ed.). Elementi vizualizacije pri pouku naravoslovja (pp. 197-215). Ljubljana: Pedagoška fakulteta. Retrieved from [http://www2.pef.uni-lj.si/kemija/prispevki/za\%20net-clanek_devetak_vogrinc.pdf], September 2012.

Wang, S. C. (1998). A Study on the Learning and Teaching Hanzi - Chinese Characters. Working papers in Educational Linguistics, 14 (1), 69-101. Retrieved from [http://www.eric.ed.gov/PDFS/ED428556.pdf ], July 2011. 
Wang, X. (2011). Which language? Which culture? Which pedagogy? A study of Mandarin Chinese teachers' perceptions of their professional self in a British school context. Tilburg Papers Culture Studies, Paper 4. Retrieved from [http://www.tilburguniversity.edu/research/institutes-and-researchgroups/babylon/tpcs/paper4.pdf ], August 2012

Woolfolk, A. (2002): Pedagoška psihologija [Pedagocical psychology]. Ljubljana: Educy.

Xia, W. (2011). Teaching Communication in the Chinese as a Foreign Language Classroom. All Graduate Reports and Creative Projects, Paper 18. Retrieved from [http://digitalcommons.usu.edu/gradreports/18 ], August 2012.

Xiao, Y. (2006). Discourse Features and Development in Chinese L2 Writing. In M. E., Everson \& H. H., Shen (eds.). Research Among Learners of Chinese as a Foreign Language (pp. 133-152). University of Hawai'i at Mānoa: National Foreign Language Resource Center.

Xing, J. Z. (2006): Teaching and Learning Chinese as a Foreign Language. A Pedagogical Grammar. Hong Kong: Hong Kong University Press.

Yang, C. W. (2006). The Enlightened Chinese Characters. Thesis presented in partial fulfillment of the requirements for the degree of Master of Philosophy. South Africa: University of Stellenbosch. Retrieved from [http://scholar.sun.ac.za/bitstream/handle/10019.1/2428/Yang.pdf?sequence=1], February 2012.

Yang, J. (ed.) (2002). 汉语教程第一册上 [Chinese course]. Beijing: Beijing yuyan wenhua daxue chubanshe.

Yao, X. (2000): An introduction to Confucianism. Cambridge: Cambridge University Press. Retrieved from [http://catdir.loc.gov/catdir/samples/cam032/99021094.pdf in http://books.google.si/books?id=tAE2OJ9bPG0C\&printsec=frontcover\&hl=sl\#v=onep age\&q\&f=false], August 2012.

Ye, L. (2011). Teaching and Learning Chinese as a Foreign Language in the United States: To Delay or Not to Delay the Character Introduction. Applied Linguistics and English as a Second Language Dissertations, paper 21. Retrieved from [http://digitalarchive.gsu.edu/alesl_diss/21], July 2012. 
